\title{
Genetisk perinatalepidemiologi; status presens
}

\author{
Rolv Terje Lie \\ Institutt for global helse og samfunnsmedisin, UiB og Folkehelseinstituttet \\ rolv.lie@uib.no
}

This is an open access article distributed under the Creative Commons Attribution Licence, which permits unrestricted use, distribution, and reproduction in any medium, provided the original work is properly cited.

Genetisk perinatalepidemiologi er studier av genetiske årsaker til sykdom og andre uønskede utfall under svangerskapet og like etter fødsel. Historisk sett, og i et globalt perspektiv er død, både for mor og barn, utfall med betydelig risiko. Men $i$ vår del av verden har risikoen for død sunket betydelig og andre utfall er blitt relativt viktigere. Dødeligheten for barnet rundt fødsel (perinatal dødelighet) har fortsatt å falle og er nå på under 5 per 1000 fødte i Norge (tall fra Medisinsk fødselsregister 2015). En stadig viktigere kategori av utfall er medfødte misdannelser. En alvorlig medfødt misdannelse forekommer hos vel $2,4 \%$ av alle nyfødte i Europa (Dolk 2014) og har samlet sett vært nokså konstant over tid. Medfødte misdannelser er derfor blitt et relativt større helseproblem blant nyfødte. Jeg vil avgrense denne statusrapporten for genetisk perintalepidemiologi til medfødte misdannelser og spesielt leppe- og ganespalte hvor det har vært betydelig forskning på genetiske årsaker de siste tiår.

\section{HøY GJENTAGELSESRISIKO FOR MISDANNELSER}

Medisinsk fødselsregister (MFR) var tidlig ute med å publisere tall for gjentagelsesrisiko for medfødte misdannelser i familier. Alt i 1994 ble risikoen for gjentagelse fra et søsken til neste søsken beregnet for alle ICD-hovedkategorier av misdannelser (Lie 1994). Samlet sett var risikoen 7,6 (95\% KI: 6,5-9,0) ganger øket for at neste søsken skulle få samme type misdannelse som et eldre søsken hadde. Det var knapt noen øket risiko for at søsken skulle få andre typer misdannelser. Gjentagelsesrisikoen er altså nokså avgrenset til samme type misdannelse. Dette kan tolkes som at den genetiske disposisjonen er nokså spesifikk for en bestemt type misdannelse og ikke for misdannelser generelt. Kategorier som hadde spesielt høy gjentagelsesrisiko var leppespalte, hvor gjentagelsesrisikoen var 31 (1952) ganger forhøyet og ganespalte som hadde en 45 (9134) ganger forhøyet risiko hos yngre søsken av barn med ganespalte. Disse kategoriene med høy gjentagelsesrisiko er også blant de vanligste med en forekomst på vel 2 per 1000 blant alle nyfødte.

Det skulle gå nesten 10 år til før MFR hadde lang nok oppfølging av de første årgangene (den første fra 1967) til at det var mulig å studere gjentagelse av misdannelser hos barn av de som vokste opp og etter hvert ble foreldre (Skjærven 1999). Tallene for gjentagelse fra mor til barn var nokså like gjentagelsestendensen fra et søsken til det neste. Samlet sett var risikoen 6,8
(4,5-10) ganger forhøyet for at barnet skulle få samme type misdannelse som den mor var født med. For leppespalte var risikoen 38 (17-77) ganger forhøyet og tilsvarende 82 (13-290) for ganespalte. Gjentagelse fra far til barn fulgte også et lignende mønster med liten risiko for å gjenta andre misdannelser enn den far eventuelt var født med. Samlet sett var risiko for å gjenta samme misdannelse 6,5 ganger øket (4-10). For leppespalte var risikoen igjen 38 ganger øket (14-93) (Lie 2001).

Resultatene viste at misdannelser har spesifikke genetiske årsaker og at det genetiske bidraget til risiko antagelig er betydelig. Ettersom gjentagelse fra en generasjon til neste (både fra mor og fra far) var omtrent like høy som fra et søsken til neste, bidrar antagelig miljøfaktorer som vedvarer fra et svangerskap til det neste og derved er like for søsken, mye mindre til risikoen enn det genetikk gjør. Miljøfaktorer bidrar mindre til gjentagelsesrisikoen fra foreldre til barn, selv om enkelte forhold, som røyking, kan gjentas fra en generasjon til neste. Mens det genetiske bidraget, $i$ hvert fall fra barnets egne nedarvede gener, bidrar omtrent likt til gjentagelsesrisiko mellom søsken og fra foreldre til barn. Det er antagelig det siste som gjør at disse tallene er så like.

I en nyere studie av gjentagelsesrisiko for spalter ble MFR oppdatert med diagnoser fra de plastikkirurgiske avdelingene (Sivertsen 2008) for å gjøre dataene mer komplette og detaljerte. For leppespalter skilles det ofte mellom de som har en ganespalte i tillegg og de som bare har en leppespalte. Ofte avgrenses analyser av spalter også til de barna som ikke har andre misdannelser enn spalter, såkalte isolerte spalter. Det antas at disse tilfellene i mindre grad skyldes underliggende genetiske syndromer. I arbeidet til Sivertsen (2008) ble gjentagelsesrisiko beregnet for isolert leppespalte uten ganespalte (CLO), isolert leppespalte med ganespalte (CLP) og isolert ganespalte uten leppespalte (CPO). Gjentagelsesrisikoen var 37 ganger øket (18-74) for CLO, 48 ganger øket (30-77) for CLP og 58 ganger øket (32-103) for CPO. Det var knapt noen gjentagelse av CLO eller CLP etter CPO (eller gjentagelse av CPO etter CLO eller CLP). Mellom CLO og CLP var det imidlertid en betydelig tendens til gjentagelse. Dette tyder på at CLO og CLP til en viss grad er varianter av samme misdannelse og har felles genetiske årsaker, mens CPO er en separat kategori med stort sett egne årsaker. Den embryologiske utviklingen kan forklare dette ved at leppen lukkes rundt uke 6 i svangerskapet, mens ganelukking som skjer rundt uke 9 kan forstyrres 
av at leppen ikke er lukket. Leppespalte med ganespalte kan derfor oppfattes som en mer alvorlig form for leppespalte.

Gjentagelsesrisikoen fra foreldre til barn som er over 30 ganger øket for spalter er betydelig høyere enn for en rekke andre sykdommer med såkalt kompleks genetikk hvor det letes etter genetiske årsaker. Dette skulle bety at det var godt håp om å finne genetiske årsaker til leppe- og ganespalte ved hjelp av metoder i moderne genetisk forskning.

\section{MOLEKYLARGENETISKE STUDIER LETER ETTER ÅRSAKENE}

De siste tiår har det derfor vært gjort en omfattende innsats for å finne de genetiske årsakene til spalter. I Norge ble det samlet inn data i det såkalte SAMprosjektet fra familier som fikk barn med spalter gjennom de plastikkirurgiske avdelingene ved Haukeland sykehus og Rikshospitalet i perioden 1996 til 2001. Det ble samlet inn blodprøver fra både barnet og begge foreldrene. I samme periode ble det også samlet inn et kontrollmateriale ved at barn ble trukket ut tilfeldig fra MFR og invitert sammen med foreldrene til å delta. Det ble samlet inn munnhuleprøver fra disse deltagerne. For alle barna, både i pasientgruppen og kontrollgruppen, ble prøvene som brukes i nyfødtscreeningen innhentet. Studien var basert på samtykke fra foreldrene. Deltagelsesprosenten var hele $88 \%$ i pasientgruppen og $76 \%$ i kontrollgruppen, totalt med 573 familier i pasientgruppen og 762 i kontrollgruppen (Lie 2008).

Materialet fra SAM-prosjektet har vært benyttet til å studere en rekke miljøfaktorer ved at mødrene svarte på spørreskjema om forhold under svangerskapet. Det har også vært gjennomført en rekke analyser av relevante gener og mulig samspill mellom miljø og genetikk. De siste 10 årene har det vært gjennomført såkalte GWAS-studier (Genome Wide Association Studies) basert på store internasjonale konsortier, og SAM-prosjektet har inngått i noen av disse. En oppsummering av flere av GWAS-studiene er gjort av Leslie et al. (2017). I en nylig publisert studie har SAM-prosjektet samarbeidet med grupper i USA for å beregne betydningen av noen av de mest lovende genene fra GWAS-studiene for et utvalg av personer med europeisk etnisitet (Moreno 2017). De 14 viktigste markørene ligger innenfor gener og områder som er spredt ut over hele genomet: PAX7, ABCA4ARHGAP29, IRF6, THADA, 8q21.3, 8q24, FOXE1, KIAA1598-VAX1, SPRY2, TPM1, NOG1 og MAFB.
Markørene har en klar effekt både på risikoen for CLO og for CLP. Effektene er også påfallende like for de to gruppene. For enkelte av markørene er effektene betydelige med relativ risiko på opp til 4 for barn som har risikoallelet i dobbel dose (homozygote). De 14 markørene ser ikke ut til å ha noen form for interaksjon eller samspill. For $\mathrm{CPO}$ er det vanskelig å påvise effekter, slik GWAS-studiene også har vist.

\section{HVOR LANGT ER VI KOMMET?}

Dersom vi oppfatter de 14 markørene som en status presens for hvor langt vi har kommet $\mathrm{i}$ å finne de genetiske årsakene til spalter, så er det naturlig å spørre seg hvor langt vi er kommet $\mathrm{i}$ å finne forklaringen på den høye gjentagelsesrisikoen fra foreldre til barn på vel 30 ganger økning for CLO og CLP. Det sier seg selv at vi er kommet kort $\mathrm{i}$ å forklare gjentagelsesrisikoen for $\mathrm{CPO}, \mathrm{i}$ og med at vi har funnet få markører som er assosiert med denne typen spalter. Selv om det kan regnes som et gjennombrudd i forskningen for leppespalte (CLO og CLP) at det er identifisert en rekke genetiske markører som er assosiert med risiko, så forklarer de 14 genetiske markørene mindre enn et par prosent av gjentagelsesrisikoen for disse spaltene. Det betyr at vi er kommet relativt kort i arbeidet.

Arbeidet videre er avhengig av utvikling av metoder som gjør det mulig å studere mer kompliserte genetiske mekanismer og å se gener i sammenheng. Det blir viktig å kunne studere assosiasjoner med sjeldnere varianter enn det GWAS til nå har kunnet tilby. Dette forutsetter også en dypere forståelse av betydningen av den genetiske variasjonen vi studerer. Det blir viktig å forstå de biologiske mekanismene som er knyttet til de aktuelle genene og områdene av genomet som er assosiert med risiko for spalter. Vi må erkjenne at vi bare har begynt å skrape på overflaten av de genetiske årsakene til leppe- og ganespalte.

En annen begrensning for fremtidige studier vil være tilgang på data og tilgjengelige utvalgsstørrelser. I de GWAS-studiene som er blitt gjort av spalter i internasjonale konsortier inngår det opp til et par tusen pasienter og tilsvarende antall kontroller. For å studere sjeldnere genetiske markører og mer kompliserte genetiske mekanismer vil det trengs mye høyere antall. Leppe- og ganespalte er relativt homogene og vanlige kategorier av misdannelser. For andre kategorier av misdannelser som er mer sjeldne og som har en lavere risiko for gjentagelse vil det kunne bli behov for internasjonal innsats i mange tiår for å samle inn tilstrekkelig antall tilfeller til å kunne gjøre gode studier. 


\section{REFERANSER}

Dolk H, Loane M, Garne E. The prevalence of congenital anomalies in Europe. Adv Exp Med Biol 2010; 686: $349-64$

Leslie EJ, Carlson JC, Shaffer JR, Butali A, Buxó CJ, Castilla EE, Christensen K, Deleyiannis FW, Leigh Field L, Hecht JT, Moreno L, Orioli IM, Padilla C, Vieira AR, Wehby GL, Feingold E, Weinberg SM, Murray JC, Beaty TH, Marazita ML. Genome-wide meta-analyses of nonsyndromic orofacial clefts identify novel associations between FOXE1 and all orofacial clefts, and TP63 and cleft lip with or without cleft palate. Hum Genet 2017; 136 (3): 275-286.

Lie RT, Wilcox AJ, Skjærven R. A population-based study of the risk of recurrence of birth defects. $N$ Engl J Med 1994; 331 (1): 1-4.

Lie RT, Wilcox AJ, Skjærven R. Survival and reproduction among males with birth defects and risk of recurrence in their children. JAMA 2001; 285 (6): 755-60.

Lie RT, Wilcox AJ, Taylor J, Gjessing HK, Saugstad OD, Aabyholm F, Vindenes H. Maternal smoking and oral clefts: the role of detoxification pathway genes. Epidemiology 2008; 19 (4): 606-15.

Moreno Uribe LM, Fomina T, Munger RG, Romitti PA, Jenkins MM, Gjessing HK, Gjerdevik M, Christensen K, Wilcox AJ, Murray JC, Lie RT, Wehby GL. A population-based study of effects of genetic loci on orofacial clefts. J Dent Res 2017: 22034517716914.

Sivertsen Å, Wilcox AJ, Skjærven R, Vindenes HA, Åbyholm F, Harville E, Lie RT. Familial risk of oral clefts by morphological type and severity: population based cohort study of first degree relatives. $B M J$ 2008; 336 (7641): 432-4.

Skjærven R, Wilcox AJ, Lie RT. A population-based study of survival and childbearing among female subjects with birth defects and the risk of recurrence in their children. N Engl J Med 1999; 340 (14): 1057-62. 